\title{
Betelvine (Piper betle L.): A potential source for oral care
}

\author{
U. Chowdhury*, P. K. Baruah \\ Department of Botany, University of Science and Technology, Meghalaya - 793101, India
}

Received: March 16, 2020 Revised: May 13, 2020 Accepted: May 30, 2020

Published: June 08, 2020

*Corresponding Author:

U. Chowdhury

Email: chowdhury_u@

rediffmail.com

\begin{abstract}
Piper betle L. (betelvine) is a valuable crop that is widely used as masticatory and with a long past history of varied traditional uses. Betelvine possesses numerous phytochemicals with important pharmacological attributes. Active molecules such as Fluoride, Eugenol, Hydroxylchavicol, Chlorogenic acid etc. present in betelvine with potent antibacterial, antifungal as well as anti-carcinogenic properties signify tremendous prospective of the plant for the formulation of natural product based drugs for maintaining hygiene and cure of diseases in the oral cavity.
\end{abstract}

KEYWORDS: Piper betle, Piperaceae, oral, betelvine

\section{INTRODUCTION}

Piper betle L. [Figure 1] is familiar as betelvine. It is an evergreen and perennial vine belonging to the family Piperaceae that prefers a shaded environment for its growth. The plant has semi woody stems with characteristic swollen nodes. Leaves have pointed apex that are glossy and heart shaped and an alternate phyllotaxy. The plant is dioecious and flowers are very minute that remains arranged in spike inflorescence. Favourable condition for growth of betelvine is warm and humid climate of the tropics [1]

Piper betle L. is considered to have a South and Southeast Asian origin. With several varieties and chemotypes, Piper betle L. is grown in different parts of the world [2]. Betelvine is a valuable crop of India, Sri Lanka, Malaysia, Thailand, Taiwan and other Southeast Asian countries [3]. In India, betelvine is an important crop with a long history of cultivation. It is considered native to India [4] that is mainly cultivated in the states of West Bengal, Assam, Andhra Pradesh, Bihar, Tamil Nadu, Karnataka, Kerala, Maharashtra, Odisha, Madhya Pradesh and Uttar Pradesh [5]. Shoreline sandy soil with essential mineral accumulation and coastal climates of several Indian states are suitable for betelvine cultivation [6]. Around 40 different varieties of betelvine are found in India [7]. Of these different varieties of betelvine, cultivars numbering 125-150 are reported to be grown allover Indian [8] and the cultivars being named according to locality, village or town where they are extensively cultivated [9]. The plant is called by different vernacular names in discrete segments of Southeast Asia, a list of which is shown in Table 1 [10]. In India, the plant is famed as 'green gold'. The plant has also come to be well known in India because of the involvement of huge number of its population in the process of cultivation and commerce [11].

Piper betle $\mathrm{L}$. is known to the world population since very early period [12]. Traditional systems of medicine of countries like Indian, China, Latin America, West Indies etc. have extensive use of Piper betle L. [13]. Piper betle L. has been known as a source for domestic remedy for prevention as well as cure of number of diseases. The plant is known as a source for herbal cure in conditions like cold, cough, headache, bronchial asthma, rheumatism, stomachalgia, boils and abscesses, conjunctivitis, constipation, bad breath, swelling of the gums, itches, mastitis, mastoiditis, leucorrhoea, otorrhoea, cuts and injuries $[14,15]$. Chewing of betelvine leaves give a boost to the human vocal cord [16]. Leaf extract can help to get rid of eye infection and can also enhance milk production by lactating mothers [17]. There is information of use of betelvine root as a contraceptive [18,19]. Moreover, betel leaves is a good source of calcium along with other minerals that is necessary for building bones and keeping them healthy.

The most reputed use of betelvine is the use of leaves as mouth freshener and specially taken after meal. Betel leaves are chewed along with betel nut (Areca catechu) in combination with different additives like lime, kattha, cardamom, clove, fennel seeds etc., a mixture called as "betel quid" [20]. This habit of chewing betel leaves along with betel nut and different additives is considered to enhance ones vigour and capability [21, 22]. Chewing brings warmth to the body by stimulating the central nervous system. 


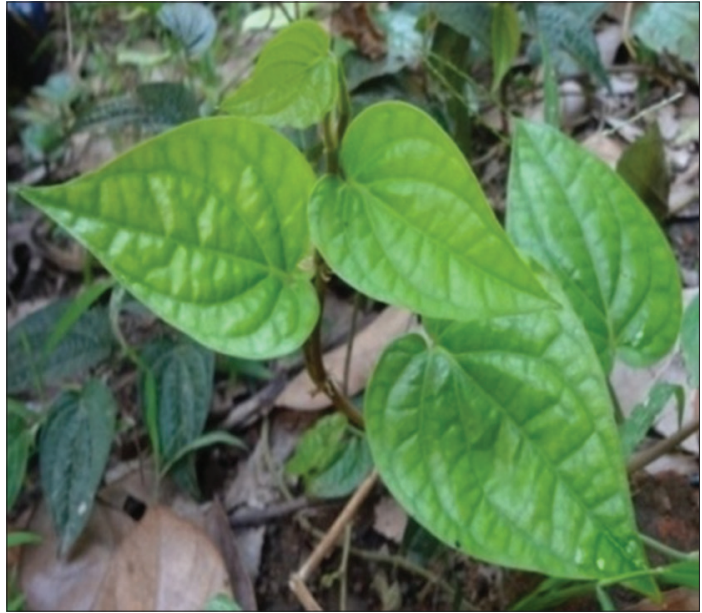

Figure 1: Piper betle L

Table 1: Vernacular names of betelvine [10]

\begin{tabular}{ll}
\hline Indian Language & Names \\
\hline Sanskrit & Nagavalli, Nagavallari, Nagini \\
Hindi, Bengal, Gujraji, Urdu & Paan \\
Kannada & Vilya, Veeleya, Villayadel \\
Konkani & Phodi paan \\
Malayalam & Vettila, Vettilakkoti \\
Marathi & Vidyache pan \\
Tamil & Vetrilai \\
Telugu & Tamalapaku \\
\hline Other Asian Languages & \\
\hline Vietnamese & Trau \\
Arabic & Tanbol \\
Mon & Plu \\
Khmer & Maluu \\
Thai & Plue \\
Sinhalese & Bulath \\
Persian & Burg-e-Tanbol \\
Chamorro & Papulu \\
Malay & Daun sirih \\
Kapampangan & Bulung samat \\
\hline
\end{tabular}

\section{BIOCHEMICAL PROFILE OF PIPER BETLE L.}

Piper betle $\mathrm{L}$. is indeed very popular and also highly investigated plant. Chemical analysis conducted on betelvine revealed presence of diverse phytochemicals, concentration of which are dependent on the prevailing climate and season [23]. Some of the phytochemicals present in betelvine are important biologically active compounds that accounts for its pharmacological and therapeutic potential. The chief phytochemical constituent of betelvine is essential oil which is responsible for its characteristic pungent aroma [24]. The essential oil of betelvine is light yellow to dark yellow in colour, present in the range between $0.1 \%$ to $2.0 \%$, depending on the variety and agro-climatic condition of the area of cultivation. A list of important constituents of betelvine oil as reported in different varieties of the plant is shown in Table 2 [25-28]. Phytochemicals present in Piper betle L. possesses antimicrobial [29], antiseptic [30], antioxidant [31], anti-inflamatory [32], anti-carcinogenic [33], anti-diabetic [34], anti-genotoxic [35], wound healing [36], anti-hemolytic [37], anti-dermatophytic [38], anti-hypercholesterolemic [39],
Table 2: Important constituents of betelvine oil [25-28]

\begin{tabular}{|c|c|c|}
\hline Compound & Molecular formula & $\begin{array}{c}\text { Molecular } \\
\text { weight }(\mathrm{g} / \mathrm{mol})\end{array}$ \\
\hline Hydroxychavicol & $\mathrm{C}_{9} \mathrm{H}_{10} \mathrm{O}_{2}$ & 150.17 \\
\hline Eugenol & $\mathrm{C}_{10}^{4} \mathrm{H}_{12} \mathrm{O}_{2}^{2}$ & 164.2 \\
\hline Eugenyl acetate & $\mathrm{C}_{12}^{10} \mathrm{H}_{14}^{12} \mathrm{O}_{3}^{2}$ & 206.241 \\
\hline Methyl isoeugenol & $\mathrm{C}_{11} \mathrm{H}_{14} \mathrm{O}_{2}^{3}$ & 178.23 \\
\hline Safrole & $\mathrm{C}_{10} \mathrm{H}_{10} \mathrm{O}_{2}^{2}$ & 162.19 \\
\hline Caryophyllene & $\mathrm{C}_{15} \mathrm{H}_{24}$ & 204.36 \\
\hline Caryophyllene oxide & $\mathrm{C}_{15} \mathrm{H}_{24} \mathrm{O}$ & 220.35 \\
\hline Silicon oil & $\mathrm{C}_{6} \mathrm{H}_{18} \mathrm{OSi}_{2}$ & 162.38 \\
\hline Campesterol & $\mathrm{C}_{28} \mathrm{H}_{48} \mathrm{O}^{2}$ & 400.68 \\
\hline Stigmasterol & $\mathrm{C}_{29}^{20} \mathrm{H}_{48} \mathrm{O}$ & 412.69 \\
\hline Sitosterol & $\mathrm{C}_{29} \mathrm{H}_{50} \mathrm{O}$ & 414.71 \\
\hline 5-(2-propenyl)-1,3-Benzodioxole & $\mathrm{C}_{10} \mathrm{H}_{10} \mathrm{O}_{2}$ & 162.185 \\
\hline 4-chromanol & $\mathrm{C}_{9} \mathrm{H}_{10} \mathrm{O}_{2}$ & 150.17 \\
\hline$\alpha$-Cadinene & $\mathrm{C}_{15} \mathrm{H}_{24}$ & 204.35 \\
\hline Terpinolene & $\mathrm{C}_{10} \mathrm{H}_{16}$ & 136.23 \\
\hline$\alpha$-Terpinene & $\mathrm{C}_{10} \mathrm{H}_{16}^{10}$ & 136.23 \\
\hline$\gamma$-Terpinene & $\mathrm{C}_{10} \mathrm{H}_{16}$ & 136.23 \\
\hline 3-Carene & $\mathrm{C}_{10} \mathrm{H}_{16}$ & 136.24 \\
\hline$\alpha$-Penene & $\mathrm{C}_{5} \mathrm{H}_{10}$ & 70.13 \\
\hline Camphene & $\mathrm{C}_{10} \mathrm{H}_{16}$ & 136.23 \\
\hline Sabinene & $\mathrm{C}_{10} \mathrm{H}_{16}$ & 136.23 \\
\hline Myrcene & $\mathrm{C}_{10} \mathrm{H}_{16}$ & 136.23 \\
\hline$\beta$-Phellandrene & $\mathrm{C}_{10} \mathrm{H}_{16}$ & 136.23 \\
\hline$\beta$-Ocimene & $\mathrm{C}_{10} \mathrm{H}_{16}$ & 136.23 \\
\hline Cis-sabinene hydrate & $\mathrm{C}_{10} \mathrm{H}_{18} \mathrm{O}$ & 154.25 \\
\hline Terpineol-4 & $\mathrm{C}_{10} \mathrm{H}_{18} \mathrm{O}$ & 154.25 \\
\hline$\beta$-Bourbonene & $\mathrm{C}_{15} \mathrm{H}_{24}$ & 204.35 \\
\hline$\beta$-Elemene & $\mathrm{C}_{15} \mathrm{H}_{24}$ & 204.35 \\
\hline Aromadendrene & $\mathrm{C}_{15} \mathrm{H}_{24}$ & 204.35 \\
\hline$\alpha$ - Farnesene & $\mathrm{C}_{15} \mathrm{H}_{24}$ & 204.35 \\
\hline$\beta$-Farnesene & $\mathrm{C}_{15} \mathrm{H}_{24}$ & 204.35 \\
\hline$\alpha$-Humulene & $\mathrm{C}_{15} \mathrm{H}_{24}$ & 204.35 \\
\hline Germacerene-B & $\mathrm{C}_{15} \mathrm{H}_{24}^{24}$ & 204.35 \\
\hline Germacerene-D & $\mathrm{C}_{15} \mathrm{H}_{24}^{24}$ & 204.35 \\
\hline$\beta$-Selinene & $\mathrm{C}_{15} \mathrm{H}_{24}^{24}$ & 204.35 \\
\hline Cubebol & $\mathrm{C}_{15} \mathrm{H}_{26} \mathrm{O}$ & 222.37 \\
\hline E-Nerolidol & $\mathrm{C}_{15} \mathrm{H}_{26} \mathrm{O}$ & 222.37 \\
\hline Spathulenol & $\mathrm{C}_{15} \mathrm{H}_{24} \mathrm{O}$ & 220.35 \\
\hline Globulol & $\mathrm{C}_{15} \mathrm{H}_{26} \mathrm{O}$ & 222.37 \\
\hline
\end{tabular}

immunomodulatory [40] and anti-asthmatic [41] properties besides several other pharmacological and therapeutic attributes.

\section{TRADITIONS OF ORAL HYGIENE USING BETELVINE}

Leaves are the most valued part of the plant with long past history of varied and traditional human use. Mention of use of betel leaves is found in ancient Sanskrit manuscripts that date back to $600-400 \mathrm{BC}$ and references are also found in ancient tales. Betel leaf extract finds frequent use as an adjuvant or is used singly for the preparation of Ayurvedic medicine and such practices are in use since thousands of years for the cure of common disease to hereditary as well as chronic disorders $[42,43]$.

Chewing betel leaves is a traditional culture prevalent in regions from South Asia eastward to the Pacific. Chewing is customarily practiced by the people of countries like Pakistan, Maldives, India, Nepal, Sri Lanka, Bhutan, Bangladesh, Burma (Myanmar), China, Laos, Thailand, Malaysia, Indonesia, Cambodia, Vietnam, Taiwan, the Philippines, Palau, Yap, Guam, Papua 
New Guinea, the Solomon Islands, and Vanuatu. There are estimated 600 betel quid chewers found globally [44]. Chewers regard that this habit of chewing helps to maintain wellbeing of the mouth [45]. In the South East Asia, betel leaves are used for the control of dental caries and for the cure of other periodontal disorder [46]. Indonesian people use betel leaves for cure of oral candidiasis [47]. Chewing betel leaves help prevent halitosis or stop bad breadth [48]. Chewing also makes the gums strong and thereby helps to conserve the teeth [49]. There is enhanced antibiotic, peroxidase and lysozyme activity in the mouth due to increase in secretion of saliva as a result of chewing betel quid. This helps in checking growth of bacteria inside the mouth and thereby protects oral tissues. Betel leaf extract possesses broad spectrum antibacterial, anifungal and antiprotozoal activity [50]. Betel leaves are used for cure of inflammations inside the oral cavity in traditional system of medicine [51].

\section{INFLUENCE OF BETELVINE EXTRACT ON ORAL PATHOGENS}

Poor cleaning of the mouth, particularly after having food results in deposition of food substances over the teeth and gums that ultimately converts into a sticky colourless film called as plaque. Dental plaque if not cleaned properly and not taken proper care it may lead to tooth decay and cavity formation, a condition called as dental caries. Plaque consists of high magnitude of microorganisms, particularly bacteria. These micro-organisms come and harbor in the plaque and thrive on the left over food substances. Dental caries gets developed in several steps. Firstly, pioneer micro-organisms adhere to dental plaque where they proliferate and form colonies. During final stages, there is aggregation of filamentous organisms and spirochetes forming a cohesive biofilm over the teeth and gums and causing damage of the both. Microorganisms harbouring dental plaque keep on releasing acid that causes acidic change inside the mouth. High concentration of acid causes erosion of the tooth enamel and lead to cavity formation. The acid then penetrates into the tooth and brings damage from the inside. Such dental erosions are irreversible that leads to a permanent loss of the tooth structure. Caries is often associated with irritations of the gum tissues. Plaque may also grow below the gums which ultimately causes breakage of the bone that supports the teeth. Dental caries is one of the commonest infectious and a painful disorder of the mouth, management of which is very difficult. For the maintenance of proper oral hygiene, often different antibiotics are generally prescribed in order to get rid of dental caries. However, administration of antibiotics for the cure of dental caries create problems like coloration of the tongue, formation of lesions within the oral cavity and may also bring problems of taste perception [52,53].

Streptococcus mutans is one of the most dominate bacterium that contributes to the development of dental caries [54,55]. It is also an early plaque colonizing bacterium. Among the oral fungal pathogens, Candida albicans is found associated with plaque in early stages. Ali et al. [56] studied the influence of betelvine extract on oral bacterial pathogens such as Escherichia coli, Staphylococcus aureus, Streptococcus mutans and Streptococcus salivarius, as well as on oral fungal pathogens such as Candida albicans. They could obtain $840 \mathrm{mg}$ GAE/g phenol content from dried betel leaves with $95 \%$ ethanol that was added to commercially available toothpaste in order to study the effect of such conjugated mixtures on oral pathogens. The conjugated mixtures showed significant zone of inhibition for both bacterial and fungal pathogens used in their experiment.

Teanpaisan et al. [57] gave a comparative account of influence of Thai traditional herbs on seven oral micro-organisms including five Gram positive cariogenic bacteria viz. Enterobacter faecalis, Lactobacillus fermentum, L. salivarius, Streptococcus sobrinus and S. mutans as well as two Gram negative oral pathogenic bacteria, Aggregatibacter actinomycetemcomitans and Fusobacterium nucleatum. Among all the traditional herbs used in their experiment, highest zone of inhibition was produced by the betelvine extract against both gram positive and gram negative bacteria. The minimum inhibitory concentration of $P$. betle L. was found in the range between 1.04 to $5.21 \mathrm{mg} / \mathrm{mL}$ and minimum bactericidal concentration ranged between 2.08 to $8.33 \mathrm{mg} / \mathrm{Ml}$. According to Teanpaisan et al., betelvine extract render impediment to the formation of bacterial biofilm on the tooth surface. Phytochemical screening revealed 4-chromanol to be a major constituent present in betelvine extract.

Caries development depends primarily on the adherence capacity of initial plaque forming bacteria such as Streptococcus mutans [58,59]. Deshpande and Kadam [60] were also able to control Streptococcus mutans by the way of treatment with betel leaf extract. They could control this bacterium by the application of methanol, ethyl acetate, petroleum ether and chloroform extracts of betel leaf. Methanol extract produced maximum zone of inhibition for this bacterium. Deshpande and Kadam reported presence of Eugenol and 4 Chromanol in extracts of betelvine. The average contant of Eugenol in extracts of certain varieties of betelvine leaves was found to be in the range of 0.659 to $1.110 \%$ and the concentration was found to vary depending on the season [61]. Eugenol reportedly has antibacterial and antifungal activities [62-64].

Cariostatic property of Eugenol was studied specifically by JingShu et al. [65]. In the experiment conducted by Jing-Shu et al., bacterial adherence capacity showed marked reduction due to treatment of bacterial cells with Eugenol. Eugenol treatment also reduced the acid production by Streptococcus mutans grown in culture. They were also able to control carious lesions in experimental rats due to topical application of Eugenol. Eugenol can counter a wide range of agent that is known to be carcinogenic in nature [66]. Euginol comprises of one free hydroxy group attached to the benzene ring that is considered very important for effective bacterial inhibition [67]

Habit of keeping betel quid in the mouth lowers incidence of oral pathogenic microflora that is responsible for dental caries and thereby check bad breathe [68]. Antimicrobial activity of the different ingredients of betel quid i.e. kattha, lime, betel leaf, betel nut, cardamom, clove and fennel seeds was tested on oral pathogens causing dental caries by Shrishailappa et al. [69]. A combined effect of all the ingredients of betel quid was also tested on the same micro-organisms. Different ingredients of 
betel quid showed varied inhibition capacity against the tested oral pathogens.

Streptococcus sanguinis, S. mitis and Actinomyces are other primary colonizers of dental plaque. Fathilah [70] coated glass plates with extracts of Piper betle L. and Psidium guajava L. and studied the adherence capacity of these oral pathogens on the glass plates. In the experiment he could observe reduced incidence of bacteria on the plant extract treated glass plates. According to Fathilah, hydrophobicity of the bacterial cells is affected by betelvine extract that causes reduced adherence and bacterial colony formation. Micrographs taken with Scanning electron microscope (SEM) showed oral pathogenic cells in non-dividing state due to treatment with betelvine extract. Betel extracts used in the experiment conducted by Fathilah showed presence of 9.25 ppm fluoride content. Fluoride is the ionic form of fluorine with cariostatic and anti-bactericidal property even at very low concentration [71-73]. According to the World Health Organization (WHO), adequate uses of fluoride can effectively reduce the problem of dental caries [74]. This fluoride is a common constituent of commercially available toothpaste that is seen to considerably bring a decline of dental caries. Fluoride prevents tooth decay by the way of making the teeth resistant to attacks from plaque bacteria, speeds up the process of remineralization and also disrupts acid production in already affected teeth [75].

Nalina and Rahim [76] also made study of oral pathogenic bacteria found in association with dental plaque. They treated Streptococcus mutans with crude aqueous extract of betelvine. According to Nalina and Rahim, betelvine extract brings damage to the bacterial cells and also lower the acid production by pathogenic bacteria. They also observed plasma membrane damage and coagulation of the nucleoid due to treatment of S. mutans with betelvine extract. Chemical analysis conducted by Nalina and Rahim revealed presence of phenolic compound, Hydroxylchavicol in betelvine. Betel leaf extract comprise of about $26 \%$ of this phenolic compound [77]. Hydroxylchavicol present in betelvine is an active antimicrobial agent [78]. Efficacy of this phenolic compound to reduce the adherent capacity of cells of $S$. mutans suggests for its usefulness for the development of antibacterial agents that would be effective against oral pathogens and for treatment of infections of the mouth [79]. Another active phenolic compound widely found in natural food substances including betelvine is Chlorogenic acid. Chlorogenic acid is also endowed with broad spectrum antimicrobial efficacy [80], including those micro-organisms that are found during early dental plaque formation, such as S. mutans [81].

\section{CONCLUSION}

Chemical profiling and bioactive properties of betelvine have been well elucidated in number of scientific studies. It is evident that betel leaves contain a number of phytoconstituents with anti-pathogenic efficacy. Betelvine extract is potentially capable of reducing adherence of the pathogenic micro-organisms on the tooth surface. It can deter primary colonizers of dental plaque. The extract of the plant is also capable of inhibiting growth and proliferation of secondary and tertiary microbial colonizers of dental plaque. By limiting pathogenic microbes on the tooth surface and hindering their subsequent growth, oral problems can be restricted. That betelvine can heal wound implies its potentiality as a prospective source for healing of infections inside the buccal cavity. The plant is endowed with number of cariostatic agents such as Fluoride, Eugenol, Hydroxylchavicol, Chlorogenic acid etc. which can reduce occurrence of pathogenic oral micro-flora and can become an important constituent of antiplaque formulation that is plant based. All these makes Piper betle L. a potential source to be used for maintenance of oral hygiene and dental care.

\section{ACKNOWLEDGEMENT}

The authors are thankful to all the faculty members on University of Science and Technology, Meghalaya and the faculty members of Gauhati University, Guwahati for providing the facilities and encouraging throughout.

\section{REFERENCES}

1. Kumar N. Betalvine (Piper betle L.) cultivation: A unique case of plant establishment under anthropogenically regulated microclimatic conditions. Indian J Hist Sci. 1999; 34(1):19-32. https://www. researchgate.net/publication/236149082

2. Guha P. Exploring Betel Leaves for Cottage Industry. Kharagpur, India: Agriculture and Food Engineering Department, IIT; 1997.

3. Punuri JB, Sharma P, Sibyala S, Tamuli R, Bora U. Piper betle-mediated green synthesis of biocompatible gold nanoparticles. Int Nano Lett. 2012; 2:18. https://link.springer.com/article/10.1186/2228-5326-2-18.

4. Ghosh R, Darin K, P Nath, Deb P. An Overview of Various Piper Species for Their Biological Activities. International Journal of Pharma Research \& Review. 2014; 3(1): 67-75.

5. Sengupta DK, Dasgupta B, Datta P. Management of foot rot of betelvine (Piper betle L.) caused by Phytophthora parasitica Dastur. J Crop Weed. 2011; 7(2): 179-183.

6. Patra B, Pal R, Paulraj R, Pradhan SN, Meena R. Minerological composition and carbon content of soil and water amongst Betel vineyards of coastal Odisha, India. SN Applied Sciences. 2020; 2: 998. https://doi.org/10.1007/s42452-020-2631-5.

7. Patra B, Pradhan SN, Das MT, Dey SK. Eco-physiological evaluation of the Betel vine varieties cultivated in Bhogarai area of Balasore district, Odisha, India for disease management and increasing crop yield. International Journal of Recent Scientific Research. 2018; 9(4): 25822-25828. doi: 10.24327/IJRSR.

8. Lakshmi BS, Naidu KC. Comparative morphoanatomy of Piper betle L. cultivars in India. Ann Biol Res. 2010; 1(2): 128-134. https://www. researchgate.net/publication/260321273.

9. Patra B, Pradhan SN. A Study on Socio-economic aspects of Betel Vine Cultivation of Bhogarai area of Balasore District, Odisha. Journal of Experimental Science.2018; 9: 13-17. doi: 10.25081/jes.2018.v9.3651.

10. Warrier PK, Nambair VPK, Ramankutty C. Indian Medicinal Plants: A Compendium of 500 Species. Arya Vaidya Sala, Kottakal, Kerala. Orient Longman; 1995.

11. Jane NS, Deshmukh AP, Joshi MS. Review of study of different diseases on betelvine plant and control measure. Int J Appl Innov Eng Manag. 2014; 3(3): 560-563.

12. Sharma ML, Rawat AKS, Khanna RK, Chowdhury AR, Raina RM. Flavour characteristics of betel leaves. Euro Cosmetics, 1996; 5:22-24.

13. Ma J, Jones SH, Marshall R, Johnson RK, Hecht SM. A DNA damaging oxoaporphine Alkaloid from Piper caninum. Journal of Natural Products. 2004; 67:1162-1164. doi: 10.1021/np040056x.

14. Gundala SR, Yang C, Mukkavilli R, Paranjpe R, Brahmbhatt M, Pannu V. Hydroxychavicol, a betel leaf component, inhibits cancer through ROS-driven DNA damage and apoptosis. Toxicol Appl Pharm. 2014; 280(1): 86-96. doi: 10.1016/j.taap.2014.07.012.

15. Agarwal T, Singh R, Shukla AD, Waris I, Gujrati A. Comparative analysis of antibacterial activity of four Piper bet/e varieties. Adv Appl Sci Res. 
2012; 3 (2): 698-705.

16. Bakhru HK. Herbs that Heal: Natural Remedies for Good Health. Orient paperbacks; 2008.

17. Vossen HAMV, Wessel M. Plant Resources of South-East Asia Stimulants. Backhuys Publisher; 2000

18. Chopra RN, Nayar SL, Chopra IC. Glossary of Indian Medicinal Plants. CSIR, New Delhi; 1956.

19. Khanra S. Paan Vittik Silpakendra (In Bengali), "Betel Leaf Based Industry". Nabanna Bharati. 1997; 30(2):169.

20. Verma A, Kumar N, Ranade SA. Genetic diversity amongst landraces of a dioecious vegetatively propagated plant, betelvine (Piper bet/e L). J Biosci. 2004; 29: 319-328. doi:10.1007/BF02702614.

21. Usmanghani K, Saeed A, Alam MT. Piper betle in Indusyunic Medicine. University of Karachi Press; 1997.

22. Norton S A. Betel consumption and consequences. J AM Acad Demt 1998; 38: 81-88. doi: 10.1016/s0190-9622(98)70543-2.

23. Dasgupta N, De B. Antioxidant activity of Piper betle L. leaf extract in vitro. Food Chem. 2004; 88: 219-224. https://doi.org/10.1016/j. foodchem.2004.01.036.

24. Bajpai V, Sharma D, Kumar B, Madhusudanan KP. Profiling of Piper bet/e Linn. cultivars by direct analysis in real time mass spectrometric technique. Biomed Chromatogr. 2010; 24(12):1283-1286. doi: 10.1002/bmc. 1437 .

25. Begam KMF, Ravichandran P, Manimekalai V. Phytochemical analysis of some selected varieties of Piper betle L. Int J Curr Pharm Res. 2018; 10: 89-93. doi: 10.22159/ijcpr.2018v10i2.25884

26. Syahidah A, Saad CR, Hassan MD, Rukayadi Y, Norazian MH, Kamarudin MS. Phytochemical Analysis, Identification and Quantification of Antibacterial Active Compounds in Betel Leaves, Piper bet/e Methanolic Extract. Pakistan Journal of Biological Sciences. 2017; 20 (2): 70-81. doi: 10.3923/pjbs.2017.70.81.

27. Das S, Parida R, Sandeep IS, Nayak S, Mohanty S. Biotechnological intervention in betelvine (Piper betle L.): A review on recent advances and future prospects. Asian Pac J Trop Med. 2016; 9(10): 938-946. doi: 10.1016/j.apjtm.2016.07.029.

28. Saxena M, Khare NK, Saxena P, Syamsundar KV, Srivastava SK. Antimicrobial activity and Chemical composition of leaf oil in two varieties of Piper bet/e from northern plains of India. Jounal of Scientific \& Industrial Research. 2014; 73: 95-99.

29. Taukooraha U, Lall N, Mahomoodally F. Piper betle L. (betel quid) shows bacteriostatic, additive, and synergistic antimicrobial action when combined with conventional antibiotics. South African Journal of Botany. 2016; 105. 133-140. doi: 10.1016/j.sajb.2016.01.006

30. Kumar N, Mishra P, Dube A, Bhattacharya S, Dikshit K, Ranade S. Piper bet/e Linn-A maligned pan Asiatic plant with an array of pharmalogical activities and prospects for drug discovery. Curr Sci. 2010; 99: 922932. https://www.researchgate.net/publication/224246691.

31. Sarma C, Prasad R, Kaur S, Singh J, Singh J, Gat Y, Garba U, Kaur D, Dhawan K. Antioxidant and antimicrobial potential of selected varieties of Piper betle L. (Betel leaf). Anais da Academia Brasileira de Ciências. 2018; 90(4): 3871-3878. doi: 10.1590/00013765201820180285

32. Poojary B, Shettar L, Trivedi DJ, Bhat KG, Setty S, Thakur SL. Piper betle $\mathrm{L}$ as a anti-inflammatory agent. International Journal of Recent Scientific Research. 2018; 9(6): 27432-27436. https://www. researchgate.net/publication/326395366.

33. Patra B, Gautam R, Priyadarsini E, Paulraj R, Pradhan SN, Muthupandian S, Meena R. Piper bet/e: Augmented synthesis of gold nanoparticles and its invitro cytotoxicity assessment on HeLa and HEK293 cells. Journal of Cluster Science. 2020. 31:133-145. https:// doi.org/10.1007/s10876-019-01625-5.

34. Perumal P, Saravanabhavan K. Antidiabetic and antioxidant activities of ethanolic extract of Piper bet/e L. leaves in catfish, Clarias gariepinus. Asian J Pharm Clin Res. 2018; 11 (3): 194-198. doi: 10.22159/ ajpcr.2018.v11i3.22393.

35. Dhote S, Devi PU, Pathak AK, Goswami RB. Studies on Anti-genotoxic Effect of Piper betle Leaves. Journal of Natural Remedies. 2007; 7(2): 247-251. doi: 10.18311/jnr/2007/316.

36. Budiman A, Khoerunnisa R, Qoriah AT. Wound-healing test of Piper betle leaf extract and Aloe vera in gel preparation. Int J App Pharm. 2018; 10(3): 86-91. doi: 10.22159/ijap.2018v10i3.24408.

37. Bhalerao SA, Verma DR, Gavankar RV, Teli NC, Rane YY, Didwana VS, Trikannad A. Phytochemistry, pharmacological profile and therapeutic uses of Piper betle Linn. - An overview. Journal of Pharmacognosy and Phytochemistry. 2013; 1(2): 10-19. https://www.researchgate. net/publication/292138168.

38. Sharma KK, Saikia R, Kotoky J, Kalita JC, Das J. Evaluation of Antidermatophytic activity of Piper betle, Allamanda cathertica and their combination: an in vitro and in vivo study. Int $\mathrm{J}$ Pharm Tech Res. 2011; 3(2): 644-651. https://www.researchgate.net/ publication/228164240.

39. Venkadeswaran K, Muralidharan AR, Annadurai T, Ruban VV, Sundararajan M, Anandhi R, Thomas PA, Geraldine P. Antihypercholesterolemic and Antioxidative Potential of an Extract of the Plant, Piper betle, and Its Active Constituent, Eugenol, in Triton WR-1339-Induced Hypercholesterolemia in Experimental Rats. Evidence-Based Complementary and Alternative Medicine. 2014. doi: org/10.1155/2014/478973.

40. Musdja MY, Nurhadiyah A, Zilhaldia, Agusta A. Immunomodulatory effect of a mixture of water extracts of betel (Piper betle L.) leaf and (Uncaria gambir Roxb.) gambier on phagocytic cells and modulation on phosphatase enzyme of mice. Asian J Pharm Clin Res. 2019; 12(11): 203-207. doi: 10.22159/ajpcr.2019.v12i11.35496.

41. Misra KH, Kodanda RB, Ranjita N, Bandyopadhyay M. Evaluation of antiasthmatic effect of ethanol Extract of Piper bet/e linn. Against histamine induced Bronchospasm in guinea pigs. International Journal of Basic and Applied Chemical Sciences. 2014; 4 (1): 67-73.

42. Arambewela LS, Arawwawala LD, Ratnasooriya WD. Antidiabetic activities of aqueous and ethanolic extracts of Piper betle leave in rats. J Ethnopharmacol. 2005; 102 (2): 239-245. doi: 10.1016/j. jep.2005.06.016

43. Sharma RN. Contribution of Ayurveda towards management of bronchial asthma. Sachitra Ayurveda. 1991; 44: 349-352.

44. Chen PH, Mahmood Q, Mariottini GL, Chiang TA, Lee KW. Adverse Health Effects of Betel Quid and the Risk of Oral and Pharyngeal Cancers. BioMed Research International. 2017. https://doi. org/10.1155/2017/3904098.

45. Niranjan R, Nivedita R, Ritu I, Chandrasekaran S. Phenolic antibacterials from Piper betle in the prevention of halitosis. J Ethnopharmacol. 2002; 183:149-152. doi: 10.1016/s0378-8741(02)00194-0.

46. Ponglux D, Wong S, Phadungcharoen T, Ruangrungsi N, Likhitwitayawuid K. Medicinal Plants. Victory Power Point Corp. Ltd. 1987.

47. Patra B, Dey SK. A Review on Piper betle. Journal of Medicinal plants Studies. 2016; 4(6): 185-192. https://www.researchgate.net/ publication/310023400.

48. Ong HC, Nordiana M. Malay ethno-medico botany in Machang Kelantan, Malaysia. Fitoterapia. 1999; 70: 502-513. https://doi. org/10.1016/S0367-326X(99)00077-5.

49. Rai MP, Thilakchand KR, Palatty PL, Rao P, Rao S, Bhat HP, Baliga MS Piper betle Linn (Betel Vine), the Maligned Southeast Asian Medicinal Plant Possesses Cancer Preventive Effects: Time to Reconsider the Wronged Opinion. Asian Pac J Cancer Prev. 2011; 12:2149-2156. https://europepmc.org/article/med/22296348.

50. Jesonbabu JN, Lakshmi KA. In vitro antimicrobial potentialities of chloroform extracts of Ethano-medicinal plant against clinically isolated human pathogens. International Journal of Pharmacy and Pharmaceutical Sciences. 2012; 4 (3): 624-626. https://www. researchgate.net/publication/289170439.

51. Satyavati GV, Raina MK, Sharma M. Medicinal Plants of India. New Delhi: Indian Council of Medical Research, New Delhi, India 1987; Vol 1.

52. Flotra L, Gjermo P, Rolla G, Waerhaug J. Side effect of chlorhexidine mouthwashes. Eur J Oral Sci. 1971; 79:119-125. doi: 10.1111/j.16000722.1971.tb02001.x

53. Addy M, Moran J. Mechanisms of stain formation on teeth, in particular associated with metal ions and antiseptics. Adv Dent Res. 1995; 9:450-456. https://doi.org/10.1177/08959374950090041601.

54. Newel WJ. Risk markers for oral diseases. Vol. 1, Dental caries: markers of high and low risk groups and individuals. Cambridge University Press; 1991.

55. Loesche WJ. Role of Streptococcus mutans in human dental decay Microbiol Rev. 1986; 50(4): 353-80.

56. Ali A, Xiao YL, Wahida PF. The fundamental study of antimicrobial activity of Piper betle extract in commercial toothpastes. Journal of Herbal Medicine. 2018; 14: 29-34. doi: 10.1016/.hermed.2018.08.001.

57. Teanpaisan R, Kawsud P, Pahumunto N, Puripattanavong J. Screening for antibacterial and antibiofilm activity in Thai medicinal plant extracts 
against oral micro-organisms. J Tradit Complement Med. 2017; 7(2): 172-177. https://doi.org/10.1016/j.jtcme.2016.06.007

58. Matsumoto M, Minami T, Sasaki H, Sobue S, Hamada S, Ooshima T. Inhibitory effects of oolong tea extract on caries-inducing properties of mutans streptococci. Caries Res. 1999; 33: 441-445. doi: $10.1159 / 000016549$.

59. Westergren G, Olsson J. Hydrophobicity and adherence of oral streptococci after repeated subculture in vitro. Infect Immun. 1983; 40: 432-435. doi: 10.1128/IAl.40.1.432-435.1983.

60. Deshpande SN, Kadam DG. Evaluation of antibacterial activity of extracts of piper bet/e (Linn.) leaves against Streptococcus mutans. WJPR. 2015; 4(11): 1040-1050. doi: 10.20959/wjpr20187-11540.

61. Chitnis KS. Quantitation of eugenol in betel leaf varieties by HPTLC. IJPSR. 2017; 4: 4858-4862. doi: 10.13040/ IJPSR.0975-8232.8(11).4858-62.

62. Marchese A, Barbieri R, Coppo E, Orhan IE, Daglia M, Nabavi SF, Izadi M, Abdollahi M, Nabavi SM, Ajami M. Antimicrobial activity of eugenol and essential oils containing eugenol: A mechanistic viewpoint. Crit Rev Microbiol. 2017; 43(6):668-689. doi: 10.1080/1040841X.2017.1295225.

63. Hu Q, Zhou M, Wei S. Progress on the antimicrobial activity research of clove oil and eugenol in the food antisepsis field. Journal of Food Science. 2018; 83(6). doi: 10.1111/1750-3841.14180.

64. Mak KK, Kamal MB, Ayuba SB, Sakirolla R, Kang YB, Mohandas K, Balijepalli MK, Ahmad SH, Pichika MR. A comprehensive review on eugenol's antimicrobial properties and industry applications: A transformation from ethnomedicine to industry. Phcog Rev. 2019;13:1-9. doi: 10.4103/phrev.phrev_46_18.

65. Jing-Shu $X$, Yao L, Xue C,Yun C. The effect of eugenol on the cariogenic properties of Streptococcus mutans and dental caries development in rats. Exp Ther Med. 2013; 5(6): 1667-1670. doi: 10.3892/etm.2013.1066.

66. Sukumaran K, Kuttan R. Inhibition of tobacco-induced mutagenesis by eugenol and plant extracts. Mutat Res. 1995; 343: 25-30. https:// doi.org/10.1016/0165-1218(95)90059-4.

67. Lopez MKN, Hadisurya M, Cornwall RG. Antimicrobial investigation and structure activity analysis of natural eugenol derivatives against several oral bacteria. J Pharm Microbiol. 2019; 5(1:1);

68. Ghanwate NA, Thakare P. Antimicrobial and synergistic activity of ingredients of betel quid on oral and enteric pathogens. Bioscience Discovery. 2012; 3(1):47-51. https://www.researchgate.net/ publication/265974924.

69. Shrishailappa B, Sujaya R Rai, Suresh B. In Vitro-antioxidant properties of Indian traditional paan and its ingredients. Indian Journal of Traditional knowledge. 2004; 3(2):187-191. https://www. researchgate.net/publication/228558840.
70. Fathilah AR. Piper betle L. and Psidium guajava L. in oral health Maintenance. Journal of Medicinal Plants Research. 2011; 5(2): 156-163. https://www.researchgate.net/publication/235759479.

71. Loveren CV. Antimicrobial activity of fluoride and its in vivo importance: Identification of research questions. Caries Research. 2001; 35(1): 65-70. doi: 10.1159/000049114.

72. Randall JP, Seow WK, Walsh LJ. Antibacterial activity of fluoride compounds and herbal toothpastes on Streptococcus mutans: an in vitro study. Australian Dental Journal. 2015; 60: 368-374. doi: 10.1111/adj.12247.

73. Wassel MO, Khattab MA. Antibacterial activity against Streptococcus mutans and inhibition of bacterial induced enamel demineralization of propolis, miswak, and chitosan nanoparticles based dental varnishes. Journal of Advanced Research. 2017; 8(4): 387-392. doi: 10.1016/j. jare.2017.05.006.

74. World Health Organization: Inadequate or excess fluoride: a major public health concern. Geneva: WHO. 2010.

75. Ullah R, Zafar MS. Oral and dental delivery of fluoride: A review. Fluoride. 2015; 48(3): 195-204. https://www.researchgate.net/ publication/280069086.

76. Nalina T, Rahim ZHA. The crude aqueous extract of Piper betle $L$. and its antibacterial effects towards Streptococcus mutans. Am J Biotechnol Biochem. 2007; 3:10-15. doi: 10.3844/ajbbsp.2007.10.15.

77. Gundala SR, Aneja R. Piper Betel Leaf: A Reservoir of Potentia Xenohormetic Nutraceuticals with Cancer-Fighting Properties. Cancer Prev Res. 2014; 7(5): 477-486. doi: 10.1158/1940-6207.CAPR-13-0355.

78. Pauli A. Antimicrobial Properties of Catechol derivatives. 3rd World Congress on Allelopathy, Tsukuba, Japan. 2002; 26-30.

79. Sharma S, Khan IA, Ali I, Ali F, Kumar M, Kumar A, Johri RK, Abdullah ST, Bani S, Pandey A, Suri KA, Gupta BD, Satti NK, Dutt P. Qazi GN. Evaluation of the antimicrobial, Antioxidant, and AntiInflammatory Activities of Hydroxychavicol for its potential use as an oral care agent. Antimicrobial Agents and Chemotherapy. 2009; 53(1): 216-222. doi:10.1128/AAC.00045-08.

80. Acosta-Smith E, Leon-Sicairos N, Tiwari S, Flores-Villaseñor $H$, Canizalez-Roman A, Kumavath R, Ghosh P, Azevedo V, Barh D. Piper bete/ Compounds Piperidine, Eugenyl Acetate, and Chlorogenic Acid Are Broad-Spectrum Anti-Vibrio Compounds that Are Also Effective on MDR Strains of the Pathogen. Pathogens. 2019; 8(2): 64. doi: 10.3390/pathogens8020064.

81. Yadav M, Kaushik M, Roshni R, Reddy P, Mehra N, Jain V, Rana R. Effect of Green Coffee Bean Extract on Streptococcus mutans Count: A Randomised Control Trial. J Clin Diagn Res. 2017; 11(5): 68-71. doi: 10.7860/JCDR/2017/25743.9898. 